\title{
Physicochemical characterization and microbiology of wheat and rye flours
}

\author{
Rossana V.C. Cardoso ${ }^{\mathrm{a}, \mathrm{b}, 1}$, Ângela Fernandes ${ }^{\mathrm{a}, 1}$, Sandrina A. Heleno ${ }^{\mathrm{a}}$, Paula Rodrigues ${ }^{\mathrm{a}}$, \\ Ana M. Gonzaléz-Paramás ${ }^{\mathrm{b}}$, Lillian Barros ${ }^{\mathrm{a}}$, Isabel C.F.R. Ferreira ${ }^{\mathrm{a}, *}$ \\ ${ }^{a}$ Centrode Investigação de Montanha (CIMO), Instituto Politécnico de Bragança, Campus de Santa Apolónia, 5300-253 Bragança, Portugal \\ ${ }^{\mathrm{b}}$ Grupode Investigación en Polifenoles (GIP), Unidad de Nutrición y Bromatología, Facultad de Farmacia, Universidad de Salamanca, Campus Miguel de Unamuno, \\ E-37007 Salamanca, Spain
}

\section{A R T I C L E I N F O}

\section{Keywords:}

Wheat flour

Rye flour

Physicochemical characterization

Mycotoxins

Microbiological analysis

\begin{abstract}
A B S T R A C T
Seven types of wheat and rye flours were studied regarding their physical and chemical properties, as well as the presence of mycotoxins and microorganisms. The results revealed that flours presented moisture and ash contents below the recommended maximum limit. They also presented a low lipid content, which helps avoiding changes in the flours' smell and taste. From the microbiological analysis, comparing the refined rye and wheat flours, the counting in the analysed microorganisms was not significantly different. The whole flours presented high contents in almost all the tested microorganisms, highlighting the molds counting for the whole wheat flour and the aerobic plate counting for the whole rye flour. None of the samples presented Salmonella spp. Aflatoxins and ochratoxin A were not detected in any of the flours. To the best of our knowledge, this is the first characterization of wheat and rye flours for Portuguese consumers.
\end{abstract}

\section{Introduction}

Rye (Secale cereale L.) is a widely grown cereal consumed as bread in northern Europe and the main producers are Russia, Poland, Germany, Belarus and Ukraine. On the other hand, wheat (Triticum aestivum L.) is originally from the Levant region of the near East and Ethiopia (Ihsan, El-nakhlawy, \& Ismail, 2015). It is the most cultivated cereal in the world, about one third of total cereals, while rye is grown at $2 \%$ worldwide. In general, rye and wheat flours are composed mainly by macronutrients such as of starch, water, proteins and other micronutrients, such as non-starch polysaccharides, lipids and ashes. Among the differences found between wheat and rye flours, the protein composition could be highlighted, being the content of prolamin and glutenin (as well as gluten) higher in wheat flours, while the content in albumins has been revealed to be higher in rye flours (Hadaruga, Costescu, Corpaş, Hədərugə, \& Isengard, 2016). The consumption of wheat, rye, and related cereals can be harmful to susceptible individuals, due to specific proteins that are responsible for triggering hypersensitivity, such as wheat allergy, celiac disease (CD), and nonceliac gluten sensitivity (NCGS) (Schalk, Lexhaller, Koehler, \& Scherf, 2017).

The chemical composition of cereal grains affects their functional and technological characteristics. Cereals are processed by crushing using different types of mills. Nevertheless, the force applied for cereals grinding, which can be implemented through compression, impact or shear, allows reducing the particle sizes according to the desired end use products. At the industrial level, complex process of crushing, successive sieving, and refining leads to the separation of the husk from the endosperm and germ resulting in several types of flours (Koletta, Irakli, Papageorgiou, \& Skendi, 2014).

In Portugal, flour type numbers indicate the degree of cereal grinding. The flour types 55, 65 or 85 are characterized by being white flours due to fine grinding. This kind of flour contains only the endosperm of the grain, because the refining process removes the husk, also destroying the grain's vitamin content. The milling process separates fibre-rich bran from the rest of the grain and the fibre content is typically lower, but contains a little more starch and gluten. The flours type 130,150 or 170 are made from the bran of the grain and give rise to a darker bread, preserving all the dietary and nutritious characteristics, containing several vitamins, high fibre content and unsaturated fat (Koletta et al., 2014).

Standard Portuguese wheat flours range from type 55-65 (white wheat flour) used in pastry, to type 150 (wholemeal flour) used in pastas and whole grain bread. Standards rye flours range from type $70-$ 85 (semi-integral flour) used in bakery, to type 130-170 (wholemeal flours) and give bread strong increasing darkness (Weekendbakery, ,

\footnotetext{
* Corresponding author.

E-mail address: iferreira@ipb.pt (I.C.F.R. Ferreira).

${ }^{1}$ Both authors contributed equally.
} 
2018).

According to the Portuguese Society of Nutrition and Food Sciences (SPCNA, 2003), flour for the baking and pastry industry, cookies and biscuits must be conform with the analytical characteristics of wheat flour (T 55-T 150: with maximum moisture of $14.5 \%$, ash of $0.49-2 \%$, respectively, and dry gluten, $8-7 \%$ respectively) and rye flour (T 70-T 170: maximum moisture of $14.5 \%$ and ash of $0.79-2.5 \%$, respectively).

In Italy, for example, the commercial description applied to flours is based on ash content and degree of milling and the nomenclature ranges from 0 to 2 ; flours type 00 present an ash content of $0.4 \%$ and $9 \%$ of protein and flours type 2 may have $1 \%$ of ash and $15 \%$ of protein. In Germany, the nomenclature ranges between 405 and 1700, and in France between 45 and 150; and follows the same trend as Italy, which in relation to the percentage content of ash and proteins (Weekendbakery, 2018).

The type of flour, defined on the basis of the ash content, only guarantees the production of white or darker crumb bread. In the USA and United Kingdom, no numbered standardized flour types are defined, and the ash content is only rarely given in the flour label by the manufacturers. However, the legal required standard nutrition label of flours indicates the protein content and its advisable use: multipurpose, pastry, cakes, biscuits, and bread (Mata, 2006; Weekendbakery, 2018).

Although the growth of microorganisms is not sustained under such low water activity, foodborne bacteria and fungi can easily contaminate flour and survive for long time periods. Moreover, low moisture is known to increase heat resistance of foodborne pathogens. Several studies from Australia, Europe and North America report the presence of Salmonella spp., Escherichia coli, Bacillus cereus, and other deteriorating microorganisms in flour. Outbreaks of salmonellosis have also been associated with consumption of low-moisture foods, including wheat flour (Condón-Abanto, Condón, Raso, Lyng, \& Álvarez, 2016).

Besides foodborne pathogens, contamination with mycotoxins is among the most serious problems affecting the safety and quality of cereals and cereal products. The most important groups of mycotoxins frequently identified in such products are aflatoxins (AFs) and ochratoxin A (OTA), produced by several species of the genera Aspergillus and Penicillium. Cereals are considered the main contributors to mycotoxins exposure in Europe and, being generally stable compounds, mycotoxins can be transferred from the cereal grains to the processed cereal products. Several studies have confirmed the contamination of cereal flours with these mycotoxins (Torović, 2018). Due to the importance of cereals in the European diet, the European Union has set stringent regulations on AF and OTA contamination of products derived from cereals: $2 \mu \mathrm{g} / \mathrm{kg}$ for AFB1, $4 \mu \mathrm{g} / \mathrm{kg}$ for total AF, and $3 \mu \mathrm{g} / \mathrm{kg}$ for OTA (European Union, 2006a).

In this perspective, the objective of this study was to evaluate the quality of wheat and rye flours according to the degree of refinement, by determining the physicochemical as well as the occurrence of mycotoxins and microbial contaminations. The degree of refinement is coded by the used number, a higher figure represents smaller grinding and the texture obtained is denser, as lower figure refers to higher grinding, resulting in whiter and thinner flours.

\section{Materials and methods}

\subsection{Flours samples}

Seven flours representative of the commercial diversity were kindly donated by the Milling Company "Moagem do Loreto", Bragança, Portugal, in December 2017, namely T 55, T 65, T 85, T 130, T 150 and $\mathrm{T} 170$. The wheat and rye flours were divided considering the degree of refinement, namely $\mathrm{T} 55$ and $\mathrm{T} 65$ (wheat flours - refined samples), $\mathrm{T}$ 150 (whole wheat flour), T 70 and T 85 (rye flours - refined samples) and $\mathrm{T} 130$ and $\mathrm{T} 170$ (whole rye flours).

\subsection{Physicochemical analysis}

\subsubsection{Macronutrients and energetic value}

The samples were analysed for moisture, energetic value and macronutrients (fat, ash, proteins and carbohydrates) by AOAC methods (AOAC, 2016). The crude protein was evaluated by macro-Kjeldahl method $(N \times 5.7$ for wheat flour and 6.25 for rye flour) (Mariotti, Tomé, \& Mirand, 2008) using an automatic distillation and titration unit (model Pro-Nitro-A, JP Selecta, Barcelona), ash content was determined by incineration at $550 \pm 15^{\circ} \mathrm{C}$, and the crude fat was determined using a Soxhlet apparatus by extracting a known weight of powdered sample with petroleum ether. Total carbohydrates and energetic value were determined following the formulas: Total carbohydrates $(\mathrm{g} / 100 \mathrm{~g})=100-\left(m_{\text {fat }}+m_{\text {ash }}+m_{\text {proteins }}\right)$ and Energy (kcal/ $100 \mathrm{~g})=4 \times\left(m_{\text {proteins }}+m_{\text {carbohydrates }}\right)+9 \times\left(m_{\text {fat }}\right)$.

\subsubsection{Gluten determination}

A known weight of sample ( $10 \mathrm{~g})$ was placed in a mortar and $5.5 \mathrm{~mL}$ of $\mathrm{NaCl}$ solution (2\%) was added dropwise. Afterwards, the sample was stirred with the pestle, the mixture was compressed and shaped into a ball. After kneading, it was allowed to stand for 25-30 min. After this process, the samples were washed with water to remove all the starch, until the washing liquids did not turn blue with the iodine solution (I ( $0.64 \mathrm{~g})$, KI ( $2 \mathrm{~g}) 0.4 \% w / v)$. The obtained gluten was drained and extended in a watch glass, weighed (wet gluten) and placed in a drying oven at $50{ }^{\circ} \mathrm{C}$ to obtain the dry gluten (Panreac Quimica, 1977).

\subsection{3. $p H$ determination}

One gram of each flour sample was macerated in $2 \mathrm{~mL}$ of distilled water. The $\mathrm{pH}$ was measured using a calibrated digital $\mathrm{pH}$ meter (portable food and dairy pH meter HI 99161, Hanna Instruments, Woonsocket, RI, USA).

\subsection{Microbiological analysis}

\subsubsection{General sample preparation}

The preparation of samples for microbiological analysis followed the procedure described in ISO 6887-1:2003 (ISO, 2003). Flour samples $(25 \mathrm{~g})$ were mixed with $225 \mathrm{~mL}$ of buffered peptone water (BPW; Himedia, Italy) in stomacher bags and further homogenized in a stomacker equipment (ECN 710-0873, Italy) for $1 \mathrm{~min}$ at 300 units. The obtained suspensions were further diluted to obtain dilutions from $10^{-1}$ to $10^{-5}$. Each dilution was analysed in triplicate.

\subsubsection{Microorganisms analysis}

Aerobic plate count (APC): $1 \mathrm{~mL}$ of each prepared suspension was mixed with $20 \mathrm{~mL}$ of Plate Count Agar (PCA; Liofilchem, Italy) by the pour plate method, in triplicate (LOQ $=1 \log \mathrm{UFC} / \mathrm{g}$ ). The plates were further incubated in reversed position at $30^{\circ} \mathrm{C}$ for $72 \mathrm{~h}$ and counted according to ISO 4833-2:2013 (ISO, 2013).

Coliforms and E. coli: For the coliforms counting, $1 \mathrm{~mL}$ of each suspension was mixed with $20 \mathrm{~mL}$ of Violet Red Bile Lactose Agar (VRBLA; Liofilchem, Italy), by the plate method, in duplicate (LOQ = 1 log UFC/ g). For E. coli determination the medium was supplemented with 4methylumbelliferyl-beta-D-glucuronide (MUG). The plates were further incubated in reversed position at $30{ }^{\circ} \mathrm{C}$ for $48 \mathrm{~h}$ and counted according to ISO 4832:2006 (ISO, 2006).

Yeasts and molds: $0.2 \mathrm{~mL}$ of each suspension was spread in petri dishes containing $20 \mathrm{~mL}$ of Dichloran Glycerol Agar Base (DG18; Liofilchem, Italy), in duplicate (LOQ $=1.7 \log \mathrm{UFC} / \mathrm{g}$ ). The plates were further incubated in upright position at $25^{\circ} \mathrm{C}$ for: $72 \mathrm{~h}$ for yeast counting and $120 \mathrm{~h}$ for mould counting, according to ISO 21527-2:2008 (ISO, 2008).

Sulphite-reducing clostridia (SRC): $5 \mathrm{~mL}$ of each suspension were transferred to a $50 \mathrm{~mL}$ falcon tube and further heat-treated in a water bath at $80^{\circ} \mathrm{C}$ for $10 \mathrm{~min}$. The suspension was immediately cooled in ice 
and $25 \mathrm{~mL}$ of Iron Sulfite Agar (ISA; Liofilchem, Italy) were added (LOQ $=2 \mathrm{UFC} / \mathrm{g}$ ). The mixture was homogenized and allowed to solidify. Afterwards, $5 \mathrm{~mL}$ of ISA medium was added to create anaerobiosis. The falcon tubes were incubated at $30^{\circ} \mathrm{C}$ for $24-48 \mathrm{~h}$ and black spots were counted, according to ISO 15213:2003 (ISO, 2003).

Salmonella spp: To analyse the presence of Salmonella spp. $25 \mathrm{~g}$ of flour samples were homogenized in $225 \mathrm{~mL}$ of BPW and incubated for $18 \mathrm{~h}-24 \mathrm{~h}$ at $37^{\circ} \mathrm{C} \pm 1{ }^{\circ} \mathrm{C}$. Afterwards, $0.1 \mathrm{~mL}$ of this suspension was transferred to $10 \mathrm{~mL}$ of Ramba QUICK Salmonella enrichment broth (Frilabo, Portugal). The mixture was incubated for $7 \mathrm{~h} \pm 1 \mathrm{~h}$ at $41.5^{\circ} \mathrm{C} \pm 0.5^{\circ} \mathrm{C}$. Afterwards, $10 \mu \mathrm{L}$ were spread onto a Petri dish containing CHRO Magar Salmonella Plus medium (Frilabo, Portugal), which also detects lactose-positive Salmonella, meeting the requirements of ISO 6579-1: 2017 (ISO, 2017). Any presumptive positive result (purple colonies) must then be confirmed by serological or biochemical tests according to ISO 6579-1: 2017.

\subsection{Mycotoxins analysis}

Safety Considerations. For AFs and OTA handling, the security rules were carefully followed due to the high toxicity of these substances. Protective equipment was used when managing these solutions and all the materials were cleansed by autoclaving before discarding.

The reusable materials were disinfected throughout $12 \mathrm{~h}$, submerged in a $10 \%$ bleach solution and washed with distilled water (Pereira et al., 2017).

\subsubsection{Aflatoxins determination}

Aflatoxins were extracted and purified using the method recommended by VICAM for the determination of AF in corn, raw peanuts and peanut butter (AOAC, 2008a), with slight modifications. Briefly, $25 \mathrm{~g}$ of flour were extracted by stirring with sodium chloride $(5 \mathrm{~g})$ and methanol/water $(125 \mathrm{~mL}, 70: 30, v / v)$ for $20 \mathrm{~min}\left(25^{\circ} \mathrm{C}\right.$ at $\left.150 \mathrm{rpm}\right)$. The mixture was filtered through a Whatman No. 4 filter paper (SigmaAldrich Co., St. Louis, MO, USA) and an aliquot of the filtrate (15 mL) was taken and diluted with $30 \mathrm{~mL}$ of ultra-pure water. The extract was homogenized and further filtered through a Whatman glass microfiber filter (934-AH). Subsequently, the filtered extract $(15 \mathrm{~mL})$ was purified through an immunoaffinity column (AflaTest WB, VICAM, Watertown, MA, USA) by gravity, at a rate of approximately 1-2 drops/s. The column was then washed twice with $10 \mathrm{~mL}$ of ultra-pure water. AF were eluted from the column with $1 \mathrm{~mL}$ of HPLC-grade methanol, collected in a glass vial, filtered through $0.2 \mu \mathrm{m}$ nylon filters (Whatman) and analysed by HPLC (Smartline, Knauer, Berlin, Germany) coupled to a photochemical post-column derivatization reactor (PHRED unit, Aura Industries, New York, NY, USA), a fluorescence detector (FP-2020, Jasco, Easton, MD, USA) set to $\lambda$ ex $365 \mathrm{~nm}$ and $\lambda$ em $435 \mathrm{~nm}$ and using the Clarity 2.4 Software (DataApex, Prague, Czech Republic). The compounds were separated using an isocratic elution with a reversephase C18 column $(100 \mathrm{~mm} \times 4.6 \mathrm{~mm}$, Merck Chromolith Performance, Darmstadt, Germany) at $35^{\circ} \mathrm{C}$ (7971 R Grace oven). The mobile phase consisted of a mixture with water/acetonitrile/methanol (3:1:1, $v / v / v)$ with a flow rate of $0.8 \mathrm{~mL} / \mathrm{min}$ and the injection volume was $10 \mu \mathrm{L}$. AFs was identified by chromatographic comparison with the standard (Aflatoxin B + G mixture, Sigma-Aldrich Co. St. Louis, MO, EUA) and quantification was based on the fluorescence signal response (Pereira et al., 2017).

\subsubsection{Ochratoxin A determination}

A standard method for the determination of OTA in wheat (AOAC, 2008b), as described by VICAM, was used for the analysis of flours. Briefly, $50 \mathrm{~g}$ of each samples were extracted by stirring $\left(25^{\circ} \mathrm{C}\right.$ at $150 \mathrm{rpm})$ with $200 \mathrm{~mL}$ of acetonitrile:water $(6: 4, v / v)$ for $20 \mathrm{~min}$ and subsequently filtered through Whatman No. 4 filter paper. Afterwards, the extract $(10 \mathrm{~mL})$ was diluted with phosphate-buffered saline $\mathrm{pH} 7.0$ (40 mL; PBS: $\mathrm{NaCl}(8 \mathrm{~g}), \mathrm{Na}_{2} \mathrm{HPO}_{4}(1.2 \mathrm{~g}), \mathrm{KH}_{2} \mathrm{PO}_{4}(0.2 \mathrm{~g}), \mathrm{KCl}(0.2 \mathrm{~g})$ in distilled water to a total volume of $1 \mathrm{~L}$ ), and further filtered through a Whatman glass microfiber filter (934-AH). The filtered extract $(10 \mathrm{~mL})$ was purified through an Ochratest WB immunoaffinity column (VICAM, Watertown, MA, USA) and the column was washed first with PBS $(10 \mathrm{~mL})$ and then with ultra-pure water $(10 \mathrm{~mL})$. Then OTA was eluted with HPLC-grade methanol $(1.5 \mathrm{~mL})$, collected in a glass vial, filtered through $0.2 \mu \mathrm{m}$ nylon filters (Whatman) and analysed by HPLC as described above for AFs, but without the derivatization process. The fluorescence detector was set to $\lambda$ ex $330 \mathrm{~nm}$ and $\lambda$ em $465 \mathrm{~nm}$, mobile phase consisted of a mixture with water/acetonitrile/acetic acid (29.5:70:0.5, $v / v / v)$, with a flow rate of $0.8 \mathrm{~mL} / \mathrm{min}$, and the injection volume was $10 \mu \mathrm{L}$. OTA was identified by chromatographic comparison with the standard (OTA standard solution (Sigma Aldrich Co. St. Louis, MO, EUA) and quantification was based on the fluorescence signal response (Pereira et al., 2017).

\subsubsection{In-house method validation}

AF mix ( $5 \mu \mathrm{g} / \mathrm{mL}$ for AFB1 and AFG1, and $1.5 \mu \mathrm{g} / \mathrm{mL}$ for AFB2 and AFG2) and OTA ( $10 \mu \mathrm{g} / \mathrm{mL})$ standard stock solutions were prepared and stored at $-20^{\circ} \mathrm{C}$. Working standard solutions of $\mathrm{AF}(100 \mathrm{ng} / \mathrm{mL}$ for AFB1 and AFG1, and $30 \mathrm{ng} / \mathrm{mL}$ for AFB2 and AFG2) and ochratoxin A $(100 \mathrm{ng} / \mathrm{mL})$ were prepared from stock solutions daily. Precision and recovery were performed by spiking the blank sample with $10 \mu \mathrm{g} / \mathrm{kg}$ of AFB1, AFG1 and OTA, and $3 \mu \mathrm{g} / \mathrm{kg}$ of AFB2 and AFG2. One set of unspiked sample was used as blank. Each set was composed of three replicates (Pereira et al., 2017).

Instrumentation calibration parameters were determined following the methodology previously described by the authors (Arita, Calado, Venâncio, Lima, \& Rodrigues, 2014) and the recovery rates were calculated based on the three spiked replicates (flour was artificially contaminated), by calculation of the ratio of recovered AFs and OTA concentration to the known spiked concentration. Linearity, limit of detection (LOD), and limit of quantification (LOQ) were determined by three series of analyses using 6 standard solutions with concentrations ranging from 0.5 to $50 \mathrm{ng} / \mathrm{mL}$ for AFB1 and AFG1, 0.15 to $15 \mathrm{ng} / \mathrm{mL}$ for AFG1 and AFG2, and 0.1 to $20 \mathrm{ng} / \mathrm{mL}$ for OTA. LOD and LOQ were calculated according to the following equations (Arita et al., 2014): $\mathrm{LOD}=3 \times(S D / M)$ and $\mathrm{LOQ}=10 \times(S D / M)$, where $S D$ is the standard deviation of the intercept of the regression line obtained from the calibration curve, and $M$ is the slope of the line (Pereira et al., 2017).

\subsection{Statistical analysis}

In all the assays, three samples were used and the analyses were performed triplicate. The results were expressed as mean \pm standard deviation (SD), and the statistical parameters applied was analysis of variance (ANOVA) followed by HSD test of Tukey's with $\alpha=0.05$ (SPSS v. 23.0).

\section{Results and discussion}

\subsection{Macronutrients and energetic value}

In general, the quality of the flour is attributed to its moisture, gluten, lipid, acidity, mineral, and protein contents. These properties reflect the effect of the processing and can be used to evaluate the technological or nutritional quality of the product (Hadaruga et al., 2016).

The results of physicochemical parameters are given in Table 1 . The highest $\mathrm{pH}$ value was found in whole rye flour $\mathrm{T} 130$ (6.44) and the lowest in wheat flour T 65 (6.04). Similar results were found in wheat flours from Alegre, Brazil (5.28) (Vieira, Freitas, Silva, Barbosa, \& Silva, 2015) and in samples from Tocantins, Brazil in a range from 6.0 to 6.1 (dos Macedo, Soares, Souza, \& Morais, 2017). There are few studies reporting the determination of $\mathrm{pH}$ in wheat or rye flours. The $\mathrm{pH}$ value (hydrogenation potential) is important for detecting the treatments 
Table 1

Physicochemical analysis of different types of flour.

\begin{tabular}{|c|c|c|c|c|c|c|c|}
\hline \multirow[t]{2}{*}{ Parameter } & \multicolumn{2}{|c|}{ Wheat refined flours } & \multirow{2}{*}{$\begin{array}{l}\text { Whole wheat flour } \\
\text { T } 150\end{array}$} & \multicolumn{2}{|c|}{ Rye refined flours } & \multicolumn{2}{|c|}{ Whole rye flours } \\
\hline & T 55 & T 65 & & T 70 & T 85 & Т 130 & Т 170 \\
\hline $\mathrm{pH}$ & $6.05 \pm 0.01 \mathrm{e}$ & $6.04 \pm 0.01 \mathrm{e}$ & $6.18 \pm 0.01 d$ & $6.35 \pm 0.01 c$ & $6.41 \pm 0.01 b$ & $6.44 \pm 0.01 a$ & $6.18 \pm 0.01 d$ \\
\hline Moisture (g/100 g dw) & $14.1 \pm 0.7 a$ & $13.6 \pm 0.3 a$ & $14.7 \pm 0.2 \mathrm{a}$ & $10.1 \pm 0.1 b c$ & $9.9 \pm 0.1 b c$ & $9.3 \pm 1.3 c$ & $11.5 \pm 0.3 b$ \\
\hline Proteins $(\mathrm{g} / 100 \mathrm{~g} \mathrm{dw})$ & $13.2 \pm 0.8 b$ & $13.4 \pm 0.3 b$ & $14.6 \pm 0.3 a$ & $6.93 \pm 0.07 d$ & $7.7 \pm 0.1 \mathrm{~cd}$ & $8.2 \pm 0.2 c$ & $13.8 \pm 0.1 b$ \\
\hline Ash $(g / 100 \mathrm{~g} \mathrm{dw})$ & $0.61 \pm 0.02 \mathrm{~g}$ & $0.69 \pm 0.01 \mathrm{f}$ & $1.47 \pm 0.08 b$ & $0.85 \pm 0.01 \mathrm{e}$ & $0.99 \pm 0.03 d$ & $1.27 \pm 0.03 c$ & $1.75 \pm 0.02 \mathrm{a}$ \\
\hline Lipids (g/100 g dw) & $0.92 \pm 0.02 \mathrm{~d}$ & $0.76 \pm 0.02 \mathrm{e}$ & $1.51 \pm 0.02 b$ & $0.96 \pm 0.05 d$ & $1.29 \pm 0.02 \mathrm{c}$ & $1.31 \pm 0.01 c$ & $1.73 \pm 0.02 \mathrm{a}$ \\
\hline Carbohydrates $(\mathrm{g} / 100 \mathrm{~g} \mathrm{dw})$ & $85.2 \pm 0.8 c$ & $85.5 \pm 0.3 c$ & $82.4 \pm 0.2 \mathrm{~d}$ & $91.3 \pm 0.1 \mathrm{a}$ & $90.0 \pm 0.1 b$ & $89.2 \pm 0.1 b$ & $82.7 \pm 0.1 d$ \\
\hline Energy (kcal/100 g dw) & $402.2 \pm 0.2 \mathrm{a}$ & $401.0 \pm 0.1 b$ & $401.7 \pm 0.2 b$ & $401.4 \pm 0.2 b$ & $402.5 \pm 0.1 \mathrm{a}$ & $401.4 \pm 0.1 b$ & $401.6 \pm 0.2 b$ \\
\hline \multicolumn{8}{|l|}{ Gluten } \\
\hline Wet $(\mathrm{g} / 100 \mathrm{~g} \mathrm{mb})$ & $25.0 \pm 0.5 a$ & $25.6 \pm 0.1 \mathrm{a}$ & $19.9 \pm 0.5 b$ & nd & nd & nd & nd \\
\hline Dried $(g / 100 \mathrm{~g} \mathrm{dw})$ & $9.5 \pm 0.4 \mathrm{a}$ & $9.4 \pm 0.2 \mathrm{a}$ & $7.2 \pm 0.1 b$ & nd & nd & nd & nd \\
\hline
\end{tabular}

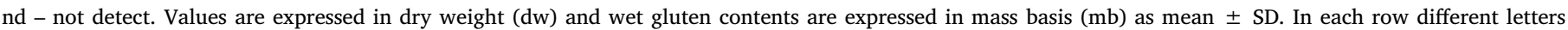
represent significant differences $(\mathrm{p}<0.05)$.

applied to the flour if it shows excessive alteration as in the case of bleaching with chlorine. It is also a significant factor for the capacity of microorganisms' development in the food. Contaminated flour contains some live yeast or other bacteria and may have a lower pH (less than 5.5) due to extra biological activity. According to this parameter, foods can be classified as: low acidity ( $\mathrm{pH}>4.5)$, acidity (4.5-4.0) and high acidity (< 4.0) (Souza, Álvares, Leite, Reis, \& Felisberto, 2008).

Regarding moisture content, the results range from $9.3 \%$ to $14.7 \%$ in whole rye flour T 130 and whole wheat flour T 150, respectively. These results are within the recommended maximum values for rye flour (14.5\%) (SPCNA, 2003). Similar results were reported in rye and wheat flours from Greece $(9.76 \%$ and $15.94 \%$, respectively) (Drakos et al., 2017). Moisture is an important parameter in the storage of flours; high levels can provide the growth of microorganisms and is a critical factor for fungi growth and mycotoxins production (Hadaruga et al., 2016). Thus, low levels are beneficial for a longer shelf-life of the product.

Protein content ranged between $6.93 \%$ and $14.6 \%$ in rye flour T 70 and in whole wheat flour T 150, respectively. Puppo, Calvelo, and Añón (2005) reported protein values of $10.9 \%$ for wheat flour from Buenos Aires, Argentina, and Drakos et al. (2017) report 9.68\% in rye flour from Greece.

Regarding the ash content, wheat flour presented similar values, namely T $55(0.61 \mathrm{~g} / 100 \mathrm{~g})$ and T $65(0.69 \mathrm{~g} / 100 \mathrm{~g})$ to those reported by Frakolaki, Giannou, Topakas, and Tzia (2018) in Greek samples $(0.63 \mathrm{~g} / 100 \mathrm{~g})$. In rye flour samples T $70(0.85 \%)$ and T $85(0.99 \%)$ revealed lower contents than those presented by Drakos et al. (2017) $(1.55 \mathrm{~g} / 100 \mathrm{~g})$. These kinds of flours are extremely white due to their high degree of refining, which result from a higher grinding with the absence of husk or germ. It is the percentage of ash that defines the commercial type of flour; the standard values for ash in wheat flour range between $0.49 \%$ and $2 \%$ and in rye flour from $0.79 \%$ to $2.5 \%$ according to the regulation $\mathrm{N}^{\circ} 254 / 2003$ (SPCNA, 2003). Otherwise, whole wheat and whole rye flours presented higher ash contents ( $\mathrm{T}$ $150-1.48 \%$, $\mathrm{T} 130-1.27 \%$ and $\mathrm{T} 170-1.75 \%$ ), since these samples contain a higher content of minerals, which do not incinerate at $550{ }^{\circ} \mathrm{C}$ (Mata, 2006).

Regarding the lipids content, the wheat flours $\mathrm{T} 55$ presented the lowest amount $(0.76 \mathrm{~g} / 100 \mathrm{~g})$ while the rye flours $\mathrm{T} 170$ presented the highest one $(1.78 \mathrm{~g} / 100 \mathrm{~g})$. Lipids are a parameter that has nutritional and physiological relevance in food because they are a source of essential fatty acids and energy. In addition, they play a key role in the quality of food and can cause unpleasant tastes and smells in stored flours. It followed the same trend of ash content, but in the present study the observed contents are lower than those reported by Bucsella, Molnár, Harasztos, and Tömösközi (2016) from Budapest, Hungary (whole wheat flour: $2.36 \%$, rye flour: $1.15 \%$ and whole rye flour: $3.07 \%)$.
The different types of flour (wheat and rye) contained comparable amounts of total carbohydrates ranging between 82.4 and $91.3 \mathrm{~g} / 100 \mathrm{~g}$. Similar results in wheat flour were reported by Kaminski, da Silva, Nascimento Júnior, and Ferrão (2011) from Santa Maria/RS - Brazil $(85.52 \mathrm{~g} / 100 \mathrm{~g})$, but, in the same study, these authors reported lower values for rye samples $(59.88 \mathrm{~g} / 100 \mathrm{~g})$. In wheat samples from Greece the authors reported $67.78 \mathrm{~g} / 100 \mathrm{~g}$ of carbohydrates (Frakolaki et al., 2018).

Concerning dry and wet gluten, these were only detected in wheat flours. Dry and wet gluten ranged from $7.2 \%$ to $9.5 \%$ and $19.9 \%$ and $25.0 \%$, respectively; being in accordance with the recommended minimum values by the Portuguese legislation (between 7 and $8 \%$ of dry gluten) (SPCNA, 2003). According to the same regulation, rye flour does not have minimum gluten values. Similar results were described in wheat flour samples from Greece, $10.90 \%$ of dry gluten and 28.24 of wet gluten (Frakolaki et al., 2018). Wheat flour has a medium to high protein content (10-16\%); higher contents are useful in industrial baking due to its higher concentration of gluten, which gives it greater elasticity and resistance to mechanical processing and influence the hydration properties present in the flours. The flours with the lowest protein content are sold as flour for household use and this is the specific characteristic that differentiates wheat from rye flours. Wheat flour presents gluten-forming proteins with capacity for mass-building, on the other hand, rye flours have less gluten-forming proteins and the high soluble fibre content impairs the formation of this protein network (Kaminski et al., 2011).

Gluten consists in a viscous and elastic mass that provides the physical and rheological characteristics such as plasticity, viscosity and elasticity important for the mass modulation. Flours need to have a considerable amount of gluten so that the dough can absorb the water. The amount and quality of gluten determine a strong water absorption and a high elasticity of the dough, which is very favourable for carbon dioxide during the fermentation process of the bakery and pastry products (Hadaruga et al., 2016).

\subsection{Microorganisms analysis}

The results regarding the microorganisms analysed in the wheat and rye flours are presented in Table 2. Aerobic mesophiles, coliforms, yeasts, molds, E. coli and sulphite-reducing clostridia were the microorganisms analysed, as well as the presence of Salmonella spp. Regarding the rye flours, the samples T 130 and $\mathrm{T} 170$ (whole flours) presented the highest contents in APC when compared with the respective refined flours $\mathrm{T} 70$ and $\mathrm{T}$ 85. In the case of coliforms, yeasts and molds, the whole sample $\mathrm{T} 170$ presented increased counts of these microorganisms when compared with the other samples. Sulphite-reducing clostridia, E. coli and Salmonella were not detected in any of the samples. As far as we know, this is the first comparative report on the 
Table 2

Analysis of microorganisms identified in the different types of flours.

\begin{tabular}{|c|c|c|c|c|c|c|c|}
\hline \multirow[t]{2}{*}{ Microorganisms analysed } & \multicolumn{2}{|c|}{ Wheat refined flours } & \multirow{2}{*}{$\begin{array}{l}\text { Whole wheat flour } \\
\text { T } 150\end{array}$} & \multicolumn{2}{|c|}{ Rye refined Flours } & \multicolumn{2}{|c|}{ Whole rye flours } \\
\hline & T 55 & T 65 & & T 70 & T 85 & Т 130 & Т 170 \\
\hline $\begin{array}{l}\mathrm{APC} \\
\qquad \mathrm{LOG}_{10} \mathrm{CFU} / \mathrm{g}\end{array}$ & 4.33 & 4.20 & 4.44 & 3.43 & 3.89 & 4.31 & 5.42 \\
\hline $\begin{array}{l}\text { Coliforms } \\
\qquad \mathrm{LOG}_{10} \mathrm{CFU} / \mathrm{g}\end{array}$ & 2.00 & 3.04 & 2.00 & 1.70 & $<\mathrm{LOQ}$ & 2.03 & 2.70 \\
\hline $\begin{array}{l}\text { Yeasts } \\
\qquad \mathrm{LOG}_{10} \mathrm{CFU} / \mathrm{g}\end{array}$ & 2.24 & 2.35 & $<\mathrm{LOQ}$ & 2.98 & 2.76 & 2.78 & 4.20 \\
\hline $\begin{array}{l}\text { Molds } \\
\qquad \mathrm{LOG}_{10} \mathrm{CFU} / \mathrm{g}\end{array}$ & 2.46 & 2.10 & 5.46 & 2.60 & 2.44 & 1.88 & 3.00 \\
\hline $\begin{array}{l}\text { Escherichia coli } \\
\text { CFU/g }\end{array}$ & $<$ LOQ & $<\mathrm{LOQ}$ & $<\mathrm{LOQ}$ & $<\mathrm{LOQ}$ & $<\mathrm{LOQ}$ & $<\mathrm{LOQ}$ & $<$ LOQ \\
\hline $\begin{array}{l}\text { SRC } \\
\qquad \mathrm{CFU} / \mathrm{g}\end{array}$ & $<2$ & $<2$ & $<2$ & $<2$ & $<2$ & $<2$ & $<2$ \\
\hline Salmonella spp. & Absent & Absent & Absent & Absent & Absent & Absent & Absent \\
\hline
\end{tabular}

APC - aerobic plate count; SRC - sulphite-reducing clostridia; CFU - colony forming units.

microbial analysis of different rye flours.

Among the wheat samples, the analysed microorganisms were present in similar amounts between wheat and whole flours, except for molds where the whole sample (T 150) presented a significant increase in these microorganisms. The APC microorganisms obtained in the present work for the wheat flours $\mathrm{T} 55$ and $\mathrm{T} 65$ (4.33 and 4.20 $\mathrm{LOG}_{10} \mathrm{CFU} / \mathrm{g}$, respectively) are in agreement with the ones obtained by Eglezos (2010) that reported a value of $4.2 \mathrm{LOG}_{10} \mathrm{CFU} / \mathrm{g}$. The same authors reported a yeast content in the order of $3.0 \mathrm{LOG}_{10} \mathrm{CFU} / \mathrm{g}$, while in the present work the counting was slightly lower ( $55=2.24$, $\mathrm{T} 65=2.35 \mathrm{LOG}_{10} \mathrm{CFU} / \mathrm{g}$ ). Also in accordance with Eglezos (2010), Salmonella was not detected in $25 \mathrm{~g}$ of sample. Khanom, Shammi, and Kabir, (2016) also reported the microorganisms' content in packed and unpacked flour samples and described the presence of $5.60 \mathrm{LOG}_{10} \mathrm{CFU} /$ $\mathrm{g}$ of total coliforms and $5.33 \mathrm{LOG}_{10} \mathrm{CFU} / \mathrm{g}$ for yeasts and molds in unpacked flours. The results regarding the content in coliforms were higher than the ones obtained in the present study ( $\mathrm{T} 55=2.00$, $\mathrm{T} 65=3.04 \mathrm{LOG}_{10} \mathrm{CFU} / \mathrm{g}$ ); as well as the content on yeasts and molds ( $55=2.65$, T65 $=2.54$ LOG $_{10}$ CFU/g). Berghofer, Hocking, Miskelly, and Jansson (2003) also reported the microbiological analysis of Australian wheat flour and reported the sample contamination with up to $10^{2} \mathrm{CFU} / \mathrm{g}$ of APC, and up to $1 \mathrm{CFU} / \mathrm{g}$ of coliforms, yeasts and molds, with countings of $10^{2} \mathrm{CFU} / \mathrm{g}$. Salmonella spp. was absent in all different flours ( $25 \mathrm{~g}$ of sample). E. coli was below the LOQ as well as SRC.

Comparing the refined rye and wheat flours, the counting in the analysed microorganisms was not significantly different. Regarding the whole samples, it is possible to state that the rye whole flour $\mathrm{T} 170$ presented a higher counting in APC microorganisms (5.42 $\mathrm{LOG}_{10} \mathrm{CFU} /$ $\mathrm{g}$ ), and in Yeasts counting (4.20 $\mathrm{LOG}_{10} \mathrm{CFU} / \mathrm{g}$ ). On the other hand, the wheat whole flour ( $\mathrm{T}$ 150) presented higher content in molds (5.46 $\mathrm{LOG}_{10} \mathrm{CFU} / \mathrm{g}$ ). Although the moisture contents are significantly different between rye and wheat samples, the microorganisms' contents were not affected by this parameter.

The cereal grains are susceptible to contamination during the ripening, harvesting, processing and storage. Microorganisms are constant contaminants of grain flours, because they originate from the cereals vegetation period, and they are an integral part of the grain mass. Under unfavourable conditions they are inactive and do not present a potential hazard (Plavšić et al., 2017).

\subsection{Mycotoxins analysis}

The calibration parameters of instrumentation (linear range, correlation coefficient $\left(R^{2}\right)$, equations of linear regression, limits of detection (LOD) and limits of quantification (LOQ) for AF and OTA are shown in Table 3 . The result for what concerns the linearity in the reference and in the calibration curves was adequate and satisfactory, with a coefficient of determination always greater than 0.999. The performance was moderately sensitive, with detection limits up to $1.2 \mu \mathrm{g} / \mathrm{kg}$ for AFs and $0.7 \mu \mathrm{g} / \mathrm{kg}$ for OTA.

The recovery and within-laboratory reproducibility are reported as the main influence to the uncertainty measurement. Other causes including mass, volume, purity of standards and calibration curve offer small contribution in the uncertainty values, not exerting significant effect on the final value (Golge \& Kabak, 2016). For that reason, recovery and repeatability of the method were determined for the matrix under analysis.

Table 4 shows the accuracy and precision of the AF and OTA analysis methods. The recovery was ascertained by spiking non-contaminated samples with known concentrations of each mycotoxin and comparison to the response obtained for pure AF and OTA standard solutions at the same concentration levels. The recoveries of AF were in the range of $70-110 \%$ regulated by the Commission Regulation (EC) No 401/2006 (European Union, 2006a), except for AFB1 which presented $64.1 \%$ of recovery. This result, which has also been reported by other authors for wheat (Torović, 2018), can be justified by the presence in the matrix of impurities such as lipids that are the main interferences with the purification step and with the chromatographic separation (Manetta, 2002). The repeatability relative standard deviations $\left(\mathrm{RSD}_{\mathrm{r}}\right)$ were 1.9-4.5\%. These values are in good agreement with the regulated performance criteria for AF, which states RSDr $<21 \%$ for AFB1 and AFG1, and RSDr $<27 \%$ for AFB2 and AFG2 (European Union, 2006a).

The recovery rate of OTA was $103 \%$, with an $\mathrm{RSD}_{\mathrm{r}}$ of $9.2 \%$. These results are in agreement with the regulated performance criteria for OTA that defines the recovery rate of $70-110 \%$, and repeatability RSDr $<21 \%$ (European Union, 2006a).

According to the European Commission Regulation 1881/2006, the maximum permissible levels (MPL) of AFB1 and total AF for all cereals and all products derived from cereals, including processed cereal products, are 2 and $4 \mu \mathrm{g} / \mathrm{kg}$ respectively. The MPL for OTA is $3 \mu \mathrm{g} / \mathrm{kg}$ for all products derived from unprocessed cereals, including processed cereal products and cereals intended for direct human consumption (European Union, 2006b). In our study, AFs and OTA were not detected in any of the samples ( $<$ LOD). These results show that the levels of mycotoxin contamination of the samples are clearly below the regulated limits, even in the case of whole flours, which retain the most contaminated parts of the grains, and wheat flours, which showed higher moisture content (between $13.6 \%$ and $14.7 \%$ ) than the rye flours (9.3\%-11.5\%) In fact, a moisture content lower than $14.5 \%$ (on a wet weight basis) is necessary to ensure that no mould spoilage or mycotoxin contamination occurs (Magan, Aldred, Mylona, \& Lambert, 2010).

Contamination of wheat flour from markets in the metropolitan 
Table 3

Calibration parameters of instrumentation for aflatoxins and ochratoxin A detection and quantification.

\begin{tabular}{|c|c|c|c|c|c|c|}
\hline Standard & & $\mathrm{AFB}_{1}$ & $\mathrm{AFB}_{2}$ & $\mathrm{AFG}_{1}$ & $\mathrm{AFG}_{2}$ & OTA \\
\hline Calibration curve & & $y=317.17 x+106.7$ & $y=905.73 x+111.38$ & $y=92.47 x+33.979$ & $y=157.79 x+17.951$ & $y=110.14 x+3.9186$ \\
\hline Correlation coefficient $\left(R^{2}\right)$ & & 0.9996 & 0.9995 & 0.9996 & 0.9992 & 0.9992 \\
\hline Linearity range (ng/mL) & & $0.5-50$ & $0.15-15$ & $0.5-50$ & $0.15-15$ & $0.1-20$ \\
\hline \multirow[t]{2}{*}{ Limits } & $\mathrm{LOD}^{\mathrm{a}}(\mu \mathrm{g} / \mathrm{kg})$ & 1.2 & 0.4 & 1.1 & 0.5 & 0.7 \\
\hline & $\mathrm{LOQ}^{\mathrm{b}}(\mu \mathrm{g} / \mathrm{kg})$ & 3.5 & 1.2 & 3.2 & 1.5 & 2.0 \\
\hline
\end{tabular}

$R^{2}$ : Correlation coefficient.

a LOD: limit of detection of the chromatographic method.

b LOQ: limit of quantification of the chromatographic method.

Table 4

Accuracy and precision of the analytical methods for aflatoxins and ochratoxin A.

\begin{tabular}{llllll}
\hline & $\mathrm{AFB}_{1}$ & $\mathrm{AFB}_{2}$ & $\mathrm{AFG}_{1}$ & $\mathrm{AFG}_{2}$ & $\mathrm{OTA}$ \\
\hline Spiking level $(\mu \mathrm{g} / \mathrm{kg})$ & 10 & 3 & 10 & 3 & 10 \\
Mean Recovery $(\%)$ & 64.1 & 72.8 & 78.0 & 87.3 & 103 \\
RSDr (\%) & 4.5 & 2.0 & 4.4 & 1.9 & 9.2
\end{tabular}

${ }^{\text {a }} \mathrm{RSD}_{\mathrm{r}}$ : Repeatability relative standard deviation.

region of Rio de Janeiro, Brazil, with AFs has been reported earlier by Trombete et al. (2014). In whole wheat flour samples $(n=26)$ and refined wheat flour $(n=15) 7.7 \%$ and $6.7 \%$, respectively were positive for at least one aflatoxin (3.4 and $1.2 \mu \mathrm{g} / \mathrm{kg}$, respectively), although at levels lower than the limit established by Brazilian legislation $(5 \mu \mathrm{g}$ / $\mathrm{kg}$ ).

Ghali, Hmaissia-khlifa, Ghorbel, Maaroufi, and Hedili (2008) evaluated samples from markets and traditional family reserves in Tunisia and reported that $31.9 \%$ of cereals samples, including wheat and derived products, were contaminated with AFs $(6.7 \mu \mathrm{g} / \mathrm{kg})$ and AFB1 $(2.2 \mu \mathrm{g} / \mathrm{kg})$, with concentrations higher than the levels established by the EU. In Bulgaria, AFs were found to be the predominant mycotoxins in wheat $(69 \%)$ with an average level of $17 \mu \mathrm{g} / \mathrm{kg}$. On the other hand, OTA was found in 16 out of $60(26.7 \%)$ wheat flour samples from Turkey, at concentrations levels of $0.247 \mu \mathrm{g} / \mathrm{kg}$ (Kara, Ozbey, \& Kabak, 2015) and in Germany samples values of $5.49 \mu \mathrm{g} / \mathrm{kg}$ were detected in rye meal bread (Zinedine, Juan, Idrissi, \& Mañes, 2007).

\section{Conclusion}

Considering the results obtained from this study, it was concluded that the physicochemical analyses of wheat and rye flours were within the limits established by the Portuguese legislation and in accordance with the information procedure in the field of technical standards and rules previewed by the European Parliament and Council, in order to safeguard the competitive capacity of the national food industries concerning the European market (European Commission, 2016). In this sense, increasing the European consumer's confidence, and the Portuguese ones in particular, in the products that they buy and consume daily. Wheat and whole wheat types ( T 55, T 65 and T 150) are appropriate for the manufacture of baked and pastry products since they had a superior amount of protein that provides a higher concentration of gluten.

On the other hand, the rye flour contains trace amounts of gluten, which makes it suitable for anyone who is trying to reduce the amount of inflammatory reaction caused by gluten in the diet; and contains complex carbohydrates, which have slower digestion and maintain satiety for longer time. Regarding the microbiological analysis, in general the whole rye samples presented higher contents in microorganisms when compared with the whole wheat flours. The wheat flours presented no significant differences between refined and whole samples, except in the molds counting (the whole samples exhibited higher content in these microorganisms). From the point of view of mycotoxins, contamination was not detected, which guarantees the safety of this product.

However, it should be stressed that the present study is a preliminary survey focused on one set of samples. It would be interesting to continue this study examining, for example, quality and safety parameters along the storage time.

\section{Declaration of interests}

None declared.

\section{Acknowledgements}

The authors are grateful to the Foundation for Science and Technology (FCT, Portugal) and FEDER under Programme PT2020 for financial support to CIMO (UID/AGR/00690/2013), L. Barros contract, A. Fernandes (SFRH/BPD/114753/2016) and S.A. Heleno (SFRH/BPD/ $101413 / 2014)$ pos-doc grants. This work is also funded by the European Regional Development Fund (ERDF) through the Regional Operational Program North 2020, within the scope of Project Mobilizador Norte-01-0247-FEDER-024479: ValorNatural ${ }^{\circledR}$.

\section{References}

AOAC, A. of O. A. C. (2016). Official methods of analysis of the Association of Official. Analytical Chemists International (20th ed.).

AOAC Official Method. (2008a). Aflatoxins in corn, raw peanuts and peanut butter: Immunoaffinity column (aflatest) method. USA

AOAC Official Method. (2008b). OchraTest HPLC Procedure for wheat. USA.

Arita, C., Calado, T., Venâncio, A., Lima, N., \& Rodrigues, P. (2014). Description of a strain from an atypical population of Aspergillus parasiticus that produces aflatoxins $\mathrm{B}$ only, and the impact of temperature on fungal growth and mycotoxin production. European Journal of Plant Pathology, 139, 655-661.

Berghofer, L. K., Hocking, A. D., Miskelly, D., \& Jansson, E. (2003). Microbiology of whea and flour milling in Australia. International Journal of Food Microbiology, 85, 137-149.

Bucsella, B., Molnár, D., Harasztos, A. H., \& Tömösközi, S. (2016). Comparison of the rheological and end-product properties of an industrial aleurone-rich wheat flour, whole grain wheat and rye flour. Journal of Cereal Science, 69, 40-48.

Condón-Abanto, S., Condón, S., Raso, J., Lyng, J. G., \& Álvarez, I. (2016). Inactivation of Salmonella typhimurium and Lactobacillus plantarum by UV-C light in flour powder. Innovative Food Science and Emerging Technologies, 35, 1-8.

Drakos, A., Kyriakakis, G., Evageliou, V., Protonotariou, S., Mandala, I., \& Ritzoulis, C. (2017). Influence of jet milling and particle size on the composition, physicochemical and mechanical properties of barley and rye flours. Food Chemistry, 215, 326-332.

Eglezos, S. (2010). Microbiological quality of wheat grain and flour from two mills in Queensland, Australia. Journal of Food Protection, 73, 1533-1536.

European Commission. (2016). The competitive position of the European food and drink industry. Brussels.

European Union. (2006). Commission Regulation (EC) No 1881/2006 of 19 February 2006 laying down the methods of sampling and analysis for the official control of the levels of mycotoxins in foodstuffs. Official Journal of the European Union, L70, 12-34.

European Union. (2006). Commission Regulation (EC) No 401/2006 of 23 February 2006 laying down the methods of sampling and analysis for the official control of the levels of mycotoxins in foodstuffs. Official Journal of the European Union, L70, 12-34.

Frakolaki, G., Giannou, V., Topakas, E., \& Tzia, C. (2018). Chemical characterization and breadmaking potential of spelt versus wheat flour. Journal of Cereal Science, 79, 50-56.

Ghali, R., Hmaissia-khlifa, K., Ghorbel, H., Maaroufi, K., \& Hedili, A. (2008). Incidence of aflatoxins, ochratoxin A and zearalenone in tunisian foods. Food Control, 19, 921-924.

Golge, O., \& Kabak, B. (2016). First report: Exposure estimates to ochratoxin A through wheat bread and rice intake in Turkey. Journal of Cereal Science, 69, 213-217. 
Hadaruga, D. I., Costescu, C. I., Corpaş, L., Hədərugə, N. G., \& Isengard, H. D. (2016). Differentiation of rye and wheat flour as well as mixtures by using the kinetics of Karl Fischer water titration. Food Chemistry, 195, 49-55.

Ihsan, M. Z., El-nakhlawy, F. S., \& Ismail, S. M. (2015). Screening Triticum aestivum L. genotypes for drought stress tolerance under arid land conditions. Journal of Aridland Agriculture, 1, 31-35.

ISO. (2003). ISO 15213 Microbiology of food and animal feeding stuffs - Horizontal method for the enumeration of sulfite-reducing bacteria growing under anaerobic conditions.

ISO. (2006). ISO 4832 Microbiology of food and animal feeding stuffs - Horizontal method for the enumeration of coliforms - Colony-count technique.

ISO (2008). ISO 21527-1/2:2008 - Microbiology of food and animal feeding stuffs Horizontal method for the enumeration of yeasts and moulds (1st ed.). Switzerland: International Standardization Organization.

ISO. (2013). ISO 4833-1 Microbiology of the food chain - Horizontal method for the enum Colony count at 30 degrees $\mathrm{C}$ by the pour plate technique.

ISO. (2017). ISO 6579-1 International Organization for Migration International Organization for Migration.

Kaminski, T. A., da Silva, L. P., Nascimento Júnior, A.do, \& Ferrão, T. dos S. (2011). Atributos nutricionais, tecnológicos e sensorias de macarrões de centeio. Brazilian Journal of Food Technology, 14, 137-144.

Kara, G. N., Ozbey, F., \& Kabak, B. (2015). Co-occurrence of aflatoxins and ochratoxin A in cereal flours commercialised in Turkey. Food Control, 54, 275-281.

Khanom, A., Shammi, T., \& Kabir, M. S. (2016). Determination of microbiological quality of packed and unpacked bread. Stamford Journal of Microbiology, 6, 24-29.

Koletta, P., Irakli, M., Papageorgiou, M., \& Skendi, A. (2014). Physicochemical and technological properties of highly enriched wheat breads with wholegrain non wheat flours. Journal of Cereal Science, 60, 561-568.

Macedo, I. dos S., Soares, L. S., De Souza, F. G., \& Morais, F. (2017). Caracterização físicoquímica das farinhas de trigo utilizadas nas panificadoras do município de paraíso do Tocantins-TO. Tocantins, Brasil: Instituto Federal do Tocantins1-8 VIII JICE, 2017.

Magan, N., Aldred, D., Mylona, K., \& Lambert, R. J. W. (2010). Limiting mycotoxins in stored wheat. Food Additives and Contaminants - Part A Chemistry, Analysis, Control, Exposure and Risk Assessment, 27, 644-650.

Manetta, A. C. (2002). Aflatoxins: Their measure and analysis. In Torres-Pacheco Irineo (Ed.). Aflatoxins - Detection, Measurement and Control (pp. 93-107). Intech.
Mariotti, F., Tomé, D., \& Mirand, P. P. (2008). Converting nitrogen into protein - Beyond 6.25 and Jones' factors. Critical Reviews in Food Science and Nutrition, 48, 177-184.

Mata, M. G. P. (2006). Os diferentes tipos de farinha.

Panreac Quimica, S. A. (1977). Cereales, derivados de cereales y cerveza - Analiticos en Alimentaria. (S. A. Panreac Quimica, Ed.), Folleto de Métodos Analíticos en Alimentaria.

Plavšić, D. V., Škrinjar, M. M., Psodorov, Đ. B., Šarić, L.Ć., Psodorov, D.Đ., Varga, A. O., \& Mandić, A. I. (2017). Mycopopulations of grain and flour of wheat, corn and buckwheat. Food and Feed Research, 44, 39-45.

Pereira, E., Barros, L., Antonio, A. L., Verde, S. C., Santos-Buelga, C., Ferreira, I. C. F. R., \& Rodrigues, P. (2017). Is gamma radiation suitable to preserve phenolic compounds and to decontaminate mycotoxins in aromatic plants? A case-study with aloysia citrodora paláu. Molecules, 22, 1-13.

Puppo, M. C., Calvelo, A., \& Añón, M. C. (2005). Physicochemical and rheological characterization of wheat flour dough. Cereal Chemistry, 82, 173-181.

Schalk, K., Lexhaller, B., Koehler, P., \& Scherf, K. A. (2017). Isolation and characterization of gluten protein types from wheat, rye, barley and oats for use as reference materials. PLoS One, 12, 1-20.

SPCNA - Sociedade Portuguesa de Ciências da Nutrição e Alimentação. g, Diário da república-I Série-B 1861 (2003). Portugal.

de Souza, J. M. L., Álvares, V. de S., Leite, F. M. N., Reis, F. S., \& Felisberto, F.Á. V. (2008). Caracterização físico-quimica de farinhas oriundas de variedades de mandioca utilizadas no vale do Juruá, Acre. Acta Amazonica, 38, 761-766.

Torović, L. (2018). Aflatoxins and ochratoxin A in flour: A survey of the Serbian retail market. Food Additives and Contaminants: Part B Surveillance, 11, 26-32.

Trombete, F. M., Moraes, D. A., Porto, Y. P., Santos, T. B., Direito, G. M., Fraga, M. E., \& Saldanha, T. (2014). Determination of Aflatoxins in Wheat and Wheat by-products Intended for Human Consumption, Marketed in Rio de Janeiro, Brazil. Journal of Food and Nutrition Research, 2, 671-674.

Vieira, T. dos S., Freitas, F. V., Silva, L. A. A., Barbosa, W. M., \& da Silva, E. M. M. (2015). Efeito da substituição da farinha de trigo no desenvolvimento de biscoitos sem glúten. Brazilian Journal of Food Technology, 18, 285-292.

Weekendbakery (2018). Understanding flour types. Retrieved from https://www. weekendbakery.com/posts/understanding-flour-types/.

Zinedine, A., Juan, C., Idrissi, L., \& Mañes, J. (2007). Occurrence of ochratoxin A in bread consumed in Morocco. Microchemical Journal, 87, 154-158. 